\title{
Hvem ejer Kafka?
}

En verserende retssag i Tel Aviv vil afgøre, hvem der skal varetage en række kasser, som i øjeblikket er opmagasineret i Zürich og Tel Aviv, indeholdende originalmanuskripter fra Kafkas hånd - deriblandt de første udkast til flere af hans publicerede værker. Kafka efterlod som bekendt sine publicerede og upublicerede værker til Max Brod, som også fik eksplicit instruks om at lade værkerne destruere efter Kafkas død. Tilsyneladende havde Kafka faktisk allerede selv brændt en stor del af sine værker. Brod nægtede at efterkomme anmodningen om at destruere de efterladte skrifter, men han udgav dog ikke hele det materiale, han havde fået testamenteret. I perioden fra 1925 til 1927 publicerede han romanerne Processen, Slottet og Amerika, og i 1935 udgav han de samlede værker. Størstedelen af det resterende materiale gemte han imidlertid væk i kufferter - måske af respekt for Kafkas ønske om, at det ikke skulle offentliggøres - men bestemt uden at ville indfri ønsket om at destruere det. Brods kompromis med sig selv på dette punkt har haft vidtrækkende konsekvenser, og i visse henseender lever vi i dag med følgerne af den uafklarede effektuering af Kafkas testamente.

I 1939 flygtede Brod fra Europa til Palæstina, og mange af manuskripterne i hans varetægt endte på The Bodleian Library i Oxford, men et betydeligt antal beholdt han selv frem til sin død i 1968. Brod testamenterede manuskripterne til sin sekretær Esther Hoffe, som han tilsyneladende havde et amourøst forhold til, og hun beholdt de fleste af dem frem til 2007, hvor hun døde i en alder af 101. Langt hen ad vejen gjorde Esther det samme som Max - hun beholdt de forskellige kasser og deponerede dem i bankbokse - men i 1988 solgte hun manuskriptet til Processen for to millioner dollars, og fra da af stod det klart, at man kunne tjene store penge på Kafka. Ingen kunne vide, at det efter Esthers død ville ende med en retssag, hvori hendes døtre Eva og Ruth hævdede, at det ikke var nødvendigt at udarbejde en fortegnelse over manuskripterne, men at deres værdi kunne opgøres alene ud fra deres vægt - helt bogstaveligt ud fra hvor meget de vejer. Som en af de advokater, der repræsenterer arven efter Hoffe, har forklaret det: "Hvis vi får en aftale på plads, vil 
materialet blive sat til salg som en samlet størrelse under ét. Det vil blive solgt efter vægt ... Man vil sige: 'Her har vi et kilo papirer, den højestbydende vil få mulighed for at se, hvad der gemmer sig i bunken.' Nationalbiblioteket [det israelske] er velkommen til at stille sig op i køen og komme med et bud ligesom alle andre."

Kafkas forvandling til handelsvare - ja faktisk til en ny guldstandard - er et vigtigt spørgsmål, som jeg vil vende tilbage til senere. I dag kommer det naturligvis ikke bag på nogen, at værdien af litterært og akademisk arbejde bliver opgjort kvantitativt, men endnu er der vist ingen, der har foreslået, at vi simpelthen vejer vores arbejde med en vægt. Lad os begynde med at se nærmere på sagens parter og deres respektive fordringer. Der er for det første det israelske nationalbibliotek, som hævder, at Esther Hoffes testamente bør tilsidesættes, eftersom Kafka ikke er disse kvinders ejendom, men enten tilhører 'almenvellet' eller det jødiske folk - med en vis tendens til sammenblanding af de to sidstnævnte størrelser. David Blumberg, som er formand for Nationalbibliotekets bestyrelse, formulerer det på denne måde: "Fra bibliotekets side har vi ikke tænkt os at give afkald på disse kulturelle aktiver tilhørende det jødiske folk ... Fordi biblioteket ikke er en kommerciel institution, men derimod giver alle adgang til sine genstande uden betaling, vil vi fortsætte vores bestræbelser på få overdraget de fundne manuskripter." Det er interessant, at Kafkas skrifter kan udgøre et 'aktiv' for det jødiske folk og samtidig være hævet over kommercielle interesser. Oren Weinberg, som er direktør for Nationalbiblioteket, har for nylig udtrykt sig på lignende måde: "Biblioteket ser med bekymring på den seneste tilkendegivelse fra eksekutorerne, som nu ønsker at blande økonomiske hensyn ind i beslutningen om, hvem der skal overtage boet. Disse skatte har ligget skjult i magasinerne i årtier, og det vil være i offentlighedens interesse at få dem bragt frem i lyset, men eksekutorernes standpunkt underminerer det tiltag af årsager, som hverken er til fordel for Israel eller verden som helhed."

Kafkas forfatterskab skal altså forstås som et 'aktiv' for det jødiske folk, men ikke som et rent økonomisk aktiv. Hvis Kafka hævdes primært at være en jødisk forfatter, vil han primært tilhøre det jødiske folk, og dermed bliver hans skrifter til kulturelle aktiver for det jødiske folk. Denne påstand, som i sig selv er problematisk (fordi den udvisker andre tilhørsformer eller rettere andre former for ikke-tilhøren), bliver endnu mere kontroversiel, når det går op for os, at retssagen er baseret på den antagelse, at det er staten Israel, der repræsenterer det jødiske folk. Dette kan måske forekomme at være en rent deskriptiv påstand, men den indebærer en række ekstraordinære og indbyrdes modstridende konsekvenser. Den overskrider for det første sondringen mellem zionistiske jøder og ikke-zionistiske diaspora-jøder, for hvem Israel hverken er det ultimative bestemmelsessted eller målet for en uundgåelig tilbagevenden. Påstanden om, at det er Israel, der repræsenterer det jødiske folk, har for det andet en række interne konsekvenser for staten Israel. Anstrengelserne for at opnå og fastholde et demografisk herredømme over statens ikke-jødiske borgere, som i dag anslås at udgøre over 20 procent af befolkningen inden for de eksisterende grænser, er faktisk baseret på det faktum, at Israel netop ikke er en udelukkende jødisk stat og derfor er nødt til at repræsentere både jødiske og ikke-jødiske borgere, hvis den skal repræsentere sin befolkning retfærdigt og ligeligt. Ved at hævde, at Israel repræsenterer det jødiske folk, fornægter man således ikke kun de utallige 
jøder uden for Israel, som hverken juridisk eller politisk er repræsenteret af staten Israel, men også de palæstinensiske og andre ikke-jødiske israelske statsborgere. Nationalbibliotekets standpunkt er baseret på en forestilling om nationen Israel, der forviser den jødiske befolkning til et liv i Galut eller afmægtigt eksil uden for det israelske territorium, en forvisning, som skal omstødes og kun kan omstødes gennem en tilbagevenden til Israel. Det implicitte ræsonnement er, at alle jøder og jødiske kulturelle aktiver - hvad det så end betyder - uden for Israel egentlig i sidste ende tilhører Israel, eftersom Israel ikke blot repræsenterer alle jøder, men også al væsentlig jødisk kulturproduktion. Lad mig blot nøjes med at anføre, at der findes en hel del interessante kommentarer til Galut-problemet blandt andet hos Amnon RazKrakotzkin, som i sit fremragende værk om eksil og suverænitet har forsøgt at vise, at eksilet er en grundlæggende egenskab ved jødedommen og ligefrem det at være jøde i det hele taget, og at zionismen derfor er på vildspor, når den mener, at eksilet må overvindes gennem påkaldelse af Loven om Tilbagevenden og ikke mindst den udbredte forestilling om 'fødselsret'. Eksil kan måske faktisk danne udgangspunkt for en refleksion over samleven og for en genindførelse af diasporiske værdier i regionen. Det var utvivlsomt også det, der var Edward Saids pointe, da han i Freud and the Non-European slog til lyd for jødernes og palæstinensernes eksilhistorier som et fælles grundlag for en ny statsdannelse i Palæstina.

Galut er ikke et fortabelsens domæne, der kræver forløsning, men det er netop en sådan fortabelse, de statslige og kulturelle former for zionisme forsøger at overvinde ved at tilkende ret til tilbagevenden til alle, der er født af jødiske mødre - og nu også ved at gøre krav på væsentlige værker skabt af folk, der tilfældigvis er af jødisk afstamning, idet sådanne værker hævdes at være jødisk kulturel kapital og dermed staten Israels retmæssige ejendom. Hvis Nationalbiblioteket kommer igennem med sit argument, vil staten Israels repræsentative fordring blive udvidet betydeligt. Som Antony Lerman formulerede det i The Guardian, hvis Nationalbiblioteket kan gøre krav på Kafkas efterladte skrifter på vegne af den jødiske stat, vil dette bibliotek og tilsvarende israelske institutioner kunne gøre krav på stort set alle de jødiske synagoger, kunstværker, manuskripter og kostbare religiøse genstande, der stadig befinder sig i Europa efter Holocaust. Men det har hverken Israel som stat eller nogen offentlig institution i Israel ret til. Kafka er bestemt en nøglefigur i den jødiske kulturbaggrund, men hans forfatterskab er i det hele taget et af de vigtigste i verden - med tematikker der finder genklang i mange forskellige lande og mange forskellige kulturer. Den israelske ejendomsfornemmelse er således helt og holdent malplaceret.

Selvom Lerman primært beklager 'Israels implicitte forrang over de jødiske samfund i Europa', har problemet også bredere globale implikationer: Hvis diasporaen tænkes som et uforløst fortabelsens domæne, vil al kulturel produktion udført af personer, der kan siges at være jøder med belæg i de rabbinerlove, der er styrende for Loven om Tilbagevenden, være underlagt posthum appropriering, forudsat at det pågældende værk kan betragtes som et 'aktiv'. Hvilket bringer mig frem til min tredje pointe, nemlig at hvor der foreligger et aktiv, da foreligger også et ejeransvar. Det er altså ikke nok, at en person eller et værk er jødisk - de må være jødiske på en sådan måde, at den israelske stat kan kapitalisere på det under sine igangværende 
kampe mod kulturel delegitimering på en række fronter. Man må forestille sig, at et aktiv er noget, der øger Israels internationale anseelse, som efter manges mening kunne trænge til et løft: Man satser simpelthen på, at Israel kan overtage Kafkas verdensomspændende anseelse. Det jødiske ejeransvar gør sig derimod gældende, når en person eller et værk, som kan hævdes at være jødisk, udgør en belastende fejl eller mangel af den ene eller den anden art: Tænk for eksempel på de seneste bestræbelser på at retsforfølge israelske menneskerettighedsorganisationer som B'tselem for at have dokumenteret og offentliggjort antallet af dræbte og sårede civile under krigen mod Gaza. Måske vil Kafka kunne instrumentaliseres med henblik på at overvinde det statustab, Israel har lidt som følge af sin vedvarende ulovlige besættelse af palæstinensisk territorium. Det er afgørende, at Israel kommer til at eje værket, men også at værket bliver opbevaret inden for statens etablerede territorium, således at enhver, der måtte ønske at se og studere værket, er nødt til at krydse den israelske grænse og indlade sig med landets kulturelle institutioner. Også det er problematisk, ikke kun fordi adskillige landes statsborgere og ikke-statsborgere fra de besatte områder ikke har lov til at krydse den grænse, men også fordi mange kunstnere og intellektuelle i øjeblikket overholder den kulturelle og akademiske boykot og nægter at optræde i Israel, medmindre den pågældende værtsinstitution gør sig til talsmand for stærk modstand mod besættelsen. Kafka-retssagen finder ikke alene sted på baggrund af denne politiske situation - den griber aktivt ind i rekonfigureringen af denne situation: Hvis Nationalbiblioteket i Jerusalem vinder sagen, vil de, der ønsker at få adgang til Franz Kafkas upublicerede og hidtil ukendte materialer, være nødt til at bryde boykotten og implicit anerkende den israelske stats ret til at appropriere særdeles værdifulde kulturgenstande, som antages at kunne smitte af på landets egen værdi som nation og konverteres til en tilsvarende høj værdi af Israel selv. Vil stakkels Kafka kunne skuldre en sådan byrde? Vil han virkelig kunne hjælpe den israelske stat med at overvinde den dårlige presse, besættelsen har givet landet?

Det er besynderligt, at Israel måske kommer til at benytte Franz Kafkas skrøbelige efterlevn som grundlag for sin kulturelle fordring på al den produktion, der er udgået fra personer, som 'kan hævdes at være jøder'. Det er formentlig heller ikke helt ligegyldigt, at modstanderne her er døtrene af en tidligere elskerinde til den overbeviste zionist Max Brod, hvis politiske interesser forekommer at blive helt overskygget af udsigten til økonomisk gevinst. Deres anstrengelser for at sikre et profitabelt udkomme forekommer - ligesom kapitalismen selv - ikke at respektere nogen nationalgrænser og har tilsyneladende ingen nationale tilhørsforhold. Faktisk ville Deutsches Literaturarchiv formentlig være et bedre bud på en institution, der kunne betale de summer, søstrene forestiller sig. I sin desperation forsøgte den israelske advokat for Nationalbiblioteket at underminere søstrenes ejerskab ved at fremlægge et af Max Brods breve, hvori han beskylder sin elskerinde for at udvise manglende respekt for ham og gør det klart, at han ville foretrække at efterlade materialerne til en, der i højere grad betragtede ham som en betydningsfuld mand. Eftersom brevet ikke sætter navn på en sådan anden person, bliver det sikkert vanskeligt at få medhold i, at det tilsidesætter den eksplicitte bestemmelse i testamentet. Det skal blive spændende at se, om denne dokumentation af et skænderi mellem to elskende bliver taget til følge i retten. 


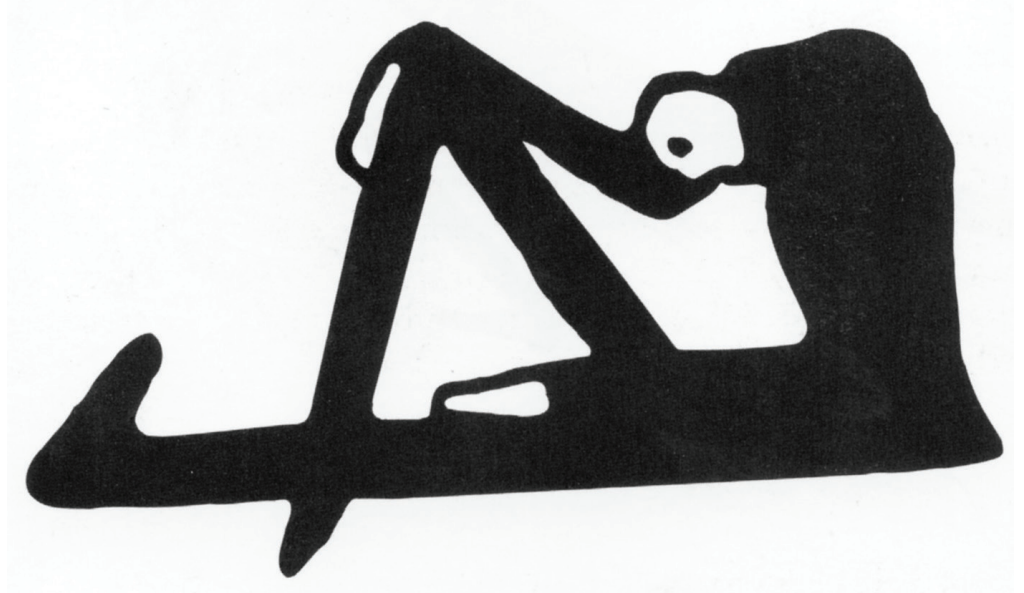

Nationalbibliotekets stærkeste rival er Deutsches Literaturarchiv i Marbach, som sjovt nok har engageret israelske advokater til retssagen. Den israelske advokatbistand har formentlig til formål at sikre, at retssagen ikke får karakter af en tyskjødisk strid og således ikke kommer til at minde om en anden retssag - processen mod Eichmann i 1961 - hvor dommeren pludselig holdt op med at tale hebræisk og henvendte sig direkte til Eichmann på tysk. Den situation skabte strid om, hvilket sprog der hører hjemme ved en israelsk domstol, og hvorvidt Eichmann havde fortjent en sådan høflighed. På det seneste har adskillige tyske universitetsfolk og aviser indvendt, at Marbach er det rette hjem for disse nye Kafka-skrifter. De påpeger, at Marbach i forvejen ejer verdens største samling af Kafka-manuskripter, deriblandt manuskriptet til Processen, som arkivet erhvervede for 3,5 millioner mark hos Sotheby's i 1988. Disse universitetsfolk argumenterer endvidere mod yderligere fragmentering af forfatterskabet og henviser til Marbach-arkivets langt større ekspertise og kapacitet, når det gælder bevaringen af sådanne materialer. Man synes at være af den opfattelse, at Tyskland, når alt kommer til alt, er et mere sikkert opbevaringssted end Israel. Men der er selvfølgelig også det argument, at Kafka tilhører tysk litteratur og nærmere bestemt det tyske sprog. Og selvom der ikke gøres fors $\varnothing \mathrm{g}$ på at hævde, at Kafka tilhører Tyskland som tidligere eller virtuel tysk statsborger, lader det alligevel til, at germaniciteten her er hævet over statsborgerskabets faktiske historie og i stedet gøres til et spørgsmål om sproglige kompetencer og bedrifter. Det tyske litteraturarkivs argumentation udvisker flersprogethedens betydning for Kafkas tilbliven og for hans skriven. (Det er faktisk et åbent spørgsmål, om vi overhovedet ville have haft Babel-parablerne, hvis det ikke var for flersprogetheden, og om kommunikationen ville vakle så vedholdende i hans værker, hvis ikke det var, fordi tjekkisk, jiddisch og tysk løb sammen hos Kafka.)

Ved at fokusere på, hvor gennemført tysk Kafkas sprog er, slutter arkivet sig til en lang, sælsom tradition for at prise Kafkas 'rene' tysk. George Steiner roste "klarheden af Kafkas tysk, dets uplettede renhed", idet han bemærkede, at Kafkas "ordvalg og syntaks er kendetegnet ved en ekstrem undgåelse af spild og fyld." John Updike refererede til "den ansporende renhed" af Kafkas prosa. Også Hannah Arendt skrev, 
at Kafkas forfatterskab "udsiger det 20. århundredes reneste tyske prosa." Selvom Kafka uomtvisteligt var tjekke, forekommer dette faktum altså at blive fortrængt af hans skrevne tysk, som angiveligt hører til blandt det reneste - eller bedst rensede - af slagsen. På baggrund af 'renhedens' historiske valorisering inden for tysk nationalisme, nationalsocialismen indbefattet, er det underligt, at Kafka bringes til at repræsentere denne rigide og ekskluderende norm. På hvilke måder må Kafkas flersprogethed og hans tjekkiske oprindelse 'renses' for at få ham stå for et rent tysk? Er det mest bemærkelsesværdige eller mest beundringsværdige ved Kafka netop dette, at han forekommer at have renset sig selv som indbegrebet af Ausländerens selvrensende formåen?

Det er interessant, at disse argumenter om Kafkas tysk kommer i omløb igen netop nu, hvor Angela Merkel har erklæret multikulturalismen mislykket i Tyskland og i den forbindelse fremfører som bevis, at nye immigranter og ikke mindst "deres børn og børnebørn" ikke taler korrekt tysk. Hun har offentligt formanet sådanne samfundsgrupper om at skille sig af med enhver form for accent og "integrere" sig i det tyske sprogfællesskabs normer (et krav, som hurtigt blev kritiseret af Jürgen Habermas). Kafka må da bestemt kunne opstilles som et eksempel på en forbilledlig immigrant, selvom han kun boede en kort overgang i Berlin og tydeligvis ikke identificerede sig med den tyske befolkning - end ikke de tyske jøder. Hvis de nye Kafka-materialer indforskrives til Marbach-arkivet, vil det styrke Tysklands bestræbelser på at omlægge sin nationalisme til et sprogligt plan: Kafka indlemmes af nøjagtig samme årsag, som man modsætter sig og fordømmer de mindre veltalende immigrationer. Kan det tænkes, at skrøbelige Kafka kommer til at danne norm for europæisk integration?

Af Kafkas korrespondance med kæresten Felice Bauer, som kom fra Berlin, fremgår det, at hun konstant rettede hans tysk, hvilket vidner om, at han ikke var helt på hjemmebane i dette andetsprog. Og hans senere kæreste, Milena Jesenská, som oversatte hans værker til tjekkisk, lærer ham hele tiden nye tjekkiske ord og vendinger, som han hverken kan udtale eller stave, hvilket vidner om, at også tjekkisk var en slags fremmedsprog for ham. I 1911 kan han gå i det jiddische teater og forstå, hvad der sagt på scenen, men jiddisch er ikke et sprog, han møder særlig ofte i sin familie eller i hverdagen. For Kafka er og bliver jiddisch et fascinerende og underfundigt indslag fra øst. Så er der overhovedet noget primærsprog her? Kunne man ligefrem hævde, at Kafkas formelle tysk - som Arendt kaldte "helt rent" tysk - bærer præg af en person, der træder ind i sproget udefra? Det var pointen i Deleuze \& Guattaris essay Kafka - for en mindre litteratur.

Det er faktisk en strid, der rækker langt tilbage i tiden, en strid, Kafka selv bringer på bane i et brev til Felice i oktober 1916 med reference til Max Brods essay om jødiske forfattere "Unsere Literaten und die Gemeinschaft" publiceret i Der Jude.

46 Og vil du så ikke lige fortælle mig, hvem jeg egentlig er. I seneste nummer af Neue Rundschau nævnes og forkastes Forvandlingen af forståelige årsager, hvorefter det hedder, at “der er noget grundlæggende tysk over K’s fortællestil.” I Max' artikel derimod kan man læse, at "K’s fortællinger hører til blandt vor tids mest jødiske dokumenter." 
"En vanskelig sag," skriver Kafka. "Er jeg da en cirkusrytter, der rider på to heste på én gang? Men, ak, jeg rider slet ikke - jeg ligger på jorden, lige så lang jeg er.”

Lad os kaste et blik på flere af Kafkas skrifter - hans breve, nogle af hans dagbogsnotater, to parabler og en fortælling - for at kaste lys over hans tilhørsforhold, hans syn på zionismen og hans mere generelle tanker om at nå frem (og ikke at nå frem til) et endemål. Hvad angår de modstridende krav om retten til de efterladte skrifter, spiller det formentlig ikke den store rolle, om Kafka var zionist eller ej, eller hvorvidt han seriøst overvejede at flytte til Palæstina. Faktum er, at Brod var zionist og tog Kafkas værker med sig, selvom Kafka aldrig selv tog af sted og aldrig rigtig havde tænkt sig at gøre det. Han forstod Palæstina som en destination, men omtalte planerne om at tage derned som 'drømme'. Det var ikke kun, fordi han manglede viljen til det, men også fordi han havde en blokerende ambivalens omkring hele projektet. Jeg håber at kunne vise, at Kafkas værker er gennemsyret af en ikke-ankomstens poetik, som også påvirker eller ligefrem hjemsøger hans kærlighedsbreve, hans parabler om rejser og hans eksplicitte refleksioner over såvel zionismen som det tyske sprog. Jeg kan sagtens forstå, at man finder det naturligt at tage udgangspunkt i, hvad Kafka har skrevet specifikt om retssager, når man ønsker at belyse den aktuelle retssag ud fra hans skrifter, men der er en række afgørende forskelle, man må være opmærksom på. Den aktuelle retssag handler om ejerskab og er til dels baseret på påstande om nationale og sproglige tilhørsforhold, men de fleste af de retssager og processer, Kafka skriver om, drejer sig snarere om ubegrundede anklager og navnløs skyld. Nu er Kafka selv blevet en ejendom for ikke at sige et pant, og kontroversen om hans endegyldige destination udspiller sig ironisk nok i familieretten i Tel Aviv. Spørgsmålet om, hvor Kafka hører til, er i sig selv noget af en skandale, i og med at hans skrifter netop kortlægger den rodløse omskiftelighed, der er forbundet med ikke at høre til nogetsteds - eller at have alt for stærkt et tilhørsforhold. Glem ikke, at Kafka ophævede alle sine forlovelser, han ejede på intet tidspunkt sin egen lejlighed, og han bad sin litterære eksekutor destruere de efterladte papirer, hvorefter også dette kontraktlige forhold skulle have ophørt men den ordning kom som bekendt til at overskride sit oprindelige formål og sin tilsigtede tidsramme. Kafka var ansat til at administrere juridiske forpligtelser og bindende kontrakter, men hans eget liv var påfaldende blottet for sådanne forhold, bortset fra lejlighedsvise forlagskontrakter. Jeg er selvfølgelig villig til at medgive, at den juridiske forvaltning af hans efterladte papirer kræver, at der bliver truffet en afgørelse om, hvem der har ansvaret for dem, og at det er nødvendigt at afklare ejerskabsproblemet, så papirerne kan blive katalogiseret og stillet til rådighed for offentligheden. Men hvis man forventer, at Kafkas skrifter vil kunne hjælpe os til at få styr på denne redelighed, vil det meget let kunne gå hen og vise sig, at disse skrifter langt snarere kan hjælpe os til at gennemtænke grænserne for kulturelle tilhørsforhold og udgrunde de faldgruber, der er indbygget i visse nationalistiske udviklingsbaner med specifikke territoriale destinationer som endemål.

Der er ingen tvivl om, at det jødiske var vigtigt for Kafka, men det indebar på ingen måde, at han havde noget bestemt syn på zionismen. Kafka fordybede sig i jødedommen, men han kæmpede også hårdt for at modstå de indimellem nærgående sociale krav, der udgik fra den. I 1911 var han i det jiddische teater næsten hver 
uge, og han beskrev alle forestillinger meget detaljeret. I de følgende år læste eller "slugte" han L'Histoire de la littérature Judéo-Allemande af Meyer Pines, som er fyldt med hassidiske fortællinger, efterfulgt af Fromers Organismus des Judentums, som indgående gennemgår de rabbinske Talmud-traditioner. Han tog til koncerter i Bar Kokhba Selskabet, læste kabbalistiske skrifter og diskuterede dem i sine dagbøger, studerede Moses Mendelssohn og Sholem Aleichem, læste adskillige jødiske magasiner, hørte foredrag om zionisme, så jiddische skuespil og lyttede til hebræiske fortællinger i oversættelse. Kafka holdt endda selv et foredrag på jiddisch, hvor han spillede på ligheden mellem 'jiddisch' og 'jargon' - måske for at vende det jiddische teaters spøgefuldhed mod jiddisch selv (Kafka 1912, uden sidetal).

Parallelt med denne imponerende fordybelse i det jødiske - frem for fordybelse burde man måske hellere omtale det som en form for omsluttethed - gav Kafka også udtryk for skepsis over for denne form for socialt tilhørsforhold. Hannah Arendt, der selv var plaget af et tilsvarende uafklaret tilhørsforhold (som blev et stridsspørgsmål mellem hende og Gershom Scholem), gjorde en af Kafkas sentenser om det jødiske folk berømt: "Mit folk, i det omfang jeg har et sådant..." Som Louis Begley for nylig har gjort klart i et ret afslørende biografisk essay, var Kafka ikke alene ambivalent omkring sin jødiske identitet, men undertiden decideret splittet. "Hvad har jeg tilfælles med jøder?” skrev han i et dagbogsnotat i 1914. “Jeg har nærmest ikke engang noget tilfælles med mig selv, og egentlig burde jeg stå lige så stille i et hjørne og bare være glad for, at jeg kan trække vejret." Indimellem kunne hans bemærkninger om jøder være barske eller ligefrem voldelige, for eksempel når han kalder det jødiske folk for "krybdyr". I et brev til Milena, som ikke var jøde, slår han over i fantasier om folkedrab og selvmord, hvor der til sidst ikke længere er nogen, der kan trække vejret:

46 Jeg burde egentlig gå i rette med dig for at have et alt for positivt syn på de jøder, du kender (mig selv indbefattet) - men også andre! Nogle gange har jeg lyst til at proppe dem alle sammen, som jøder (mig selv indbefattet), ned i en vasketøjskurv og lukke låget i og så vente lidt og åbne op igen for at se, om de alle sammen er blevet kvalt, og hvis de ikke er det, så lukke til igen og blive ved på den måde, indtil det er slut.

Det jødiske bliver igen og igen knyttet sammen med muligheden for at trække vejret. Hvad har jeg tilfælles med jøderne? Jeg er heldig med, at jeg overhovedet kan trække vejret. Så er det jøderne, der gør det svært for ham at trække vejret, eller er det Kafka, der forestiller sig at kvæle jøderne?

Kafkas kvælningsfantasi gentager en fantasmatisk størrelsesmæssig omskiftelighed, som går igen i for eksempel "Dommen". I fantasien er Kafka uvirkeligt stor, større end alle de jøder, han forestiller sig at putte ned i vasketøjskurven. Men samtidig er han selv nede i den vasketøjskurv, der gør ham ulideligt lille. I "Dommen" er faren skiftevist kæmpestor og lillebitte: På et tidspunkt bemærker sønnen Georg, at faren er så høj, at hans hånd strejfer loftet, når han står oprejst, men umiddelbart forinden er faren kun på størrelse med et barn, og Georg bærer ham i seng. Sønnen tårner sig op over faren, men bliver i næste nu dømt til døden af kraften i farens ord. Hvor er Kafka placeret i kvælningsfantasien, og hvor er Georg? De er begge under- 
kastet en vedvarende vekslen, hvor der på intet tidspunkt indfinder sig en fast målestok. I kvælningsfantasien er Kafka på én gang gerningsmand og offer. Men denne vedholdende dualitet forbliver ubemærket af dem, der har brugt dette brev som belæg for at kalde ham en selvhadende jøde. På baggrund af tekstens omskiftelighed er en sådan konklusion lige så uberettiget som den triumferende påstand, at Kafkas sporadisk beundrende bemærkninger om zionismen gør ham til zionist. I øvrigt må man ikke glemme, at nogle af disse bemærkninger trods alt falder i forbindelse med en flirt. Kvælningsfantasien, skrevet i 1920, kan måske bedst forstås i relation til et brev, Kafka skrev til Felice fire år tidligere efter at have læst Arnold Zweigs skuespil Ritualmord in Ungarn (1916). Skuespillet gengiver et drama, der udspillede sig i 1897 med udgangspunkt i antisemitiske beskyldninger om jøders brug af blod fra spædbørn. Jøderne i en ungarsk landsby beskyldes for at have brugt en slagterkniv til at dræbe kristne og derefter anvendt deres blod i usyret brød. I stykket føres de anklagede for en dommer, som afviser anklagen. Det kommer til anti-jødiske optøjer i gaderne, og jødiske forretninger og religiøse institutioner bliver angrebet. Efter at have læst Zweigs skuespil skrev Kafka til Felice: "På et tidspunkt måtte jeg afbryde læsningen og sætte mig ned på sofaen og græde." Der begynder nu at dukke slagterknive eller tilsvarende knive op i hans dagbøger og breve og i flere tilfælde også hans publicerede fiktion, for eksempel i Processen og måske mest kraftfuldt i de fortællinger, der indgår i samlingen En landlæge. Skuespillet giver os en fornemmelse af lovens begrænsninger og dens sælsomme tendens til at åbne for en lovløshed, den ikke kan kontrollere.

Det faktum, at Kafka græd over historien om de falske beskyldninger - og at det faktisk var de færreste andre beretninger, der kunne få ham til at græde på den måde - forekommer måske umiddelbart overraskende. Processen er jo immervæk holdt i en tone, hvor den falske eller uigennemskuelige anklage mod K. bliver gengivet i aldeles neutrale vendinger helt uden følelsesmæssig resonans. Det er netop den sorg, Kafka bedyrer i sine breve, der er sat ud af kraft i hans værker, men samtidig formidler værkerne en række begivenheder, der på nøjagtig samme måde hverken er forbundet gennem rimelige årsager eller logisk induktion. Skriften åbner således disjunktionen mellem klarhed - man kunne måske tale om prosaens luciditet og renhed - og den gru, der bliver normaliseret netop som følge af denne klarhed. Ingen kan sætte en finger på Kafkas grammatik og syntaks, og han er da heller aldrig blevet beskyldt for overdreven sentimentalitet i sin tone, men netop på grund af denne tilsyneladende objektivitet og strenghed i formen åbner der sig en gru midt i det hverdagslige og måske også en uudsigelig sorg. Syntaks og tematik er reelt i strid med hinanden, hvilket betyder, at man skal tænke sig om en ekstra gang, inden man begynder at prise Kafka udelukkende for hans klarhed. Luciditeten fungerer trods alt kun som stil, for så vidt den forråder sin egen fordring på selvtilstrækkelighed. Noget obskurt eller unævneligt åbner sig inden for den perfekte syntaks. I lyset af de stadigt tilbagevendende og dybt krænkende beskyldninger, der lurer i baggrunden af Kafkas mange retssager, kan man faktisk læse fortællerstemmen som en neutralisering af harmen, en sproglig nedpakning af sorgen, der paradoksalt nok bringer den frem i forgrunden. Jøderne udgør altså hans familie, hele hans lille verden, og på sin vis er han i forvejen lidt fanget i den lille lejlighed, i det ubønhørlige fællesskab - og i den forstand ved at blive 
kvalt. Og så var han jo optaget af såvel de historiske beretninger om jødeforfølgelser som den aktuelle fare for antisemitisme, som han selv havde oplevet under optøjer i 1918, hvor han pludselig befandt sig midt i en menneskeskare, der "svømmede i jødehad". Så han da zionismen som en vej ud af denne dybe ambivalens: Behovet for at flygte fra familiens og omgivelsernes snærende bånd kombineret med behovet for at finde et sted, man kunne forestille sig var blottet for antisemitisme?

Tænk blot på det første brev, Kafka skrev til Felice i september 1912. I første sætning anslår han forestillingen om de to sammen i Palæstina:

4 Idet du efter al sandsynlighed ikke længere har den fjerneste erindring om mig, vil jeg tillade mig at præsentere mig endnu en gang: Mit navn er Franz Kafka, og jeg er den person, der traf dig første gang den aften hos Brod i Prag, ham der efterfølgende, ét for ét, rakte dig fotografierne fra Thalia-rejsen hen over bordet og til sidst, med den selvsamme hånd, der nu taster disse ord, tog din hånd og bekræftede dit løfte om at ledsage ham til Palæstina næste år.

Efterhånden som korrespondancen udvikler sig i de næste par år, indskærper Kafka igen og igen, at han i virkeligheden ikke vil være i stand til at ledsage hende på denne rejse eller nogen anden rejse og da slet ikke til Palæstina - i hvert fald ikke i dette liv som den person, han er: Den hånd, der taster disse ord, vil ikke holde hendes hånd. Ydermere har han sin tvivl om zionismen og om muligheden for nogensinde at nå målet. Efterfølgende kalder han det en "drøm”, og få år senere irettesætter han hende for tage zionismen så alvorligt: "Du flirtede med den," skrev han. Men faktisk var det ham, der bragte Palæstina på bane som et strukturerende element i deres flirt: Kom med mig, tag min hånd og lad os følges ad til en anden verden. Efterhånden som forholdet går i stykker i løbet af en kort årrække, gør han det klart, at han ikke har tænkt sig at tage af sted, og at de mennesker, der rent faktisk rejser derned, er faldet for en illusion. Palæstina er et figuralt 'andetsteds', hvortil elskende kan rejse, en åben fremtid, betegnelsen for en ukendt destination.

I Kafka Goes to the Movies viser Hanns Zischler, at det var filmbilleder, der var Kafkas primære forbindelse til det palæstinensiske rum, og at Palæstina for ham var et filmisk billede, et projiceret fantasifelt. Zischler skriver, at Kafka så det elskede land på film og som film. Man forestillede sig Palæstina som et ubefolket land, hvilket bekræftes meget overvisende af Ilan Pappes arbejde om det tidlige zionistiske fotografi, hvori de palæstinensiske bebyggelser hurtigt omdøbes og gøres til en del af det naturlige landskab. Zischlers tese er interessant, men formentlig ikke helt rigtig, eftersom disse film først kom frem i 1921 ifølge de optegnelser, vi har adgang til i dag. I øvrigt fulgte Kafka ivrigt med i møderækker og tidsskrifter om Palæstina, og han fik i lige så høj grad et indtryk af Palæstina gennem skriftlige og mundtlige fortællinger og gennem offentlige debatter. Via sådanne debatter og rapporter forstod Kafka, at der var konflikter under opsejling i regionen. Hans egen novelle "Sjakaler og arabere", publiceret i Der Jude i 1917, aftegner netop zionismens konstitutive hårdknude. I denne historie forvilder fortælleren sig ind i ørkenen, hvor han møder sjakalerne (die Schakale) - en slet skjult reference til jøderne. Efter af have behandlet ham som en messiansk figur, som de har ventet på gennem generationer, forkla- 
rer de ham, at det er hans opgave at dræbe arabere med en saks (hvilket måske er en spøgefuld henvisning til, at de jødiske skræddere fra Østeuropa er dårligt udrustet til konflikt). De vil ikke selv gøre det, for det ville ikke være 'rent', men messias-figuren er åbenbart ikke bundet af kosher-indskrænkninger. Fortælleren taler derefter med den arabiske leder, som forklarer: "Det er jo almindelig kendt; så længe der har været arabere, har denne saks vandret gennem ørkenen og vil vandre med os indtil dagenes ende. Hver europæer får den tilbudt til det store værk; hver europæer er netop den, som synes dem kaldet." (Kafka 2008a, 169).

Fortællingen blev skrevet og udgivet i 1917, det år, hvor Kafka og Felice afbrød forbindelsen. Samme år understreger han over for hende i et brev: "Jeg er ikke zionist." Kort forinden skriver han til Grete Bloch, at han af temperament er "afskåret fra alle sjæleligt opbyggelige fællesskaber" på grund af sin "ikke-zionistiske (jeg beundrer zionismen og finder den samtidig kvalmende) og ikke-praktiserende jødedom." Efter at have deltaget i et zionistisk møde i marts 1915 sammen med Max Brod, hvor jøder fra Øst- og Vesteuropa samledes for at løse deres konflikter, beskriver Kafka de forskellige typer blandt de deltagende. Der er ham "i den lille, luvslidte jakke", og så er der ham med det "ubehageligt diabolske smil" og "fistelstemmen", der beskrives som et "omvandrende argument". Disse beskrivelser ender med at inddrage Kafka selv: "Og selv ligner jeg en, der er lavet af træ, som et tøjstativ, der bliver skubbet ind midt i rummet. Men stadig håber."

Hvorfra er det helt præcist, at dette håb udgår? Her vedrører destinationens problematik, som altid hos Kafka, spørgsmålet om emigration til Palæstina, men også det mere generelle spørgsmål om, hvorvidt budskaber kan nå frem, og hvorvidt befalinger kan forstås korrekt. Ikke-ankomsten betegner det sproglige vilkår at skrive inden for en flersproget kontekst, hvor man udnytter formel tysk syntaks til at skabe en sælsomt fremmedgørende effekt, men også det sproglige vilkår at skrive inden for rammerne af et moderne Babel, hvor hverdagens talesituation, det være sig amorøst eller politisk, er kendetegnet ved sprogsvigt. Det spørgsmål, der dukker op igen i parabler som "Et kejserligt budskab", er spørgsmålet om, hvorvidt et budskab kan sendes herfra og dertil, eller hvorvidt man kan rejse herfra og dertil eller 'derhen' - hvorvidt en forventet ankomst overhovedet er mulig.

Jeg vil kort se nærmere på to parabler, der begge berører ikke-ankomstens problematik og det mærkværdige håb, der kan udgå fra den bristede socialitet og den anti-messianistiske hårdknude, der karakteriserer parabel-formen. "Opbruddet" begynder med en befaling, der ikke bliver forstået: "Jeg befalede, at min hest skulle hentes frem af stalden. Tjeneren forstod mig ikke." (Kafka 2008b, 292). Befalingen afgives måske på et sprog, tjeneren ikke forstår, eller også fungerer det pågældende hierarki ikke længere efter hensigten. Yderligere kognitiv forvirring følger, idet jegfortælleren fortsætter: "I det fjerne hørte jeg lyden af en trompet, jeg spurgte ham, hvad det betød." Denne gang lader det til, at tjeneren faktisk forstår spørgsmålet, men at fortælleren ikke lever i den gængse lydverden: "Han vidste ingenting og havde ingenting hørt." Det har tjeneren åbenbart kun indikeret ved hjælp af tegn og fagter, men i næste sætning demonstrerer han faktisk sin sproglige kompetence: "Ved porten standsede han mig og spurgte: 'Hvor rider du hen, herre?", hvortil fortælleren umiddelbart efter svarer: "Jeg ved det ikke [...] blot væk herfra, blot væk 


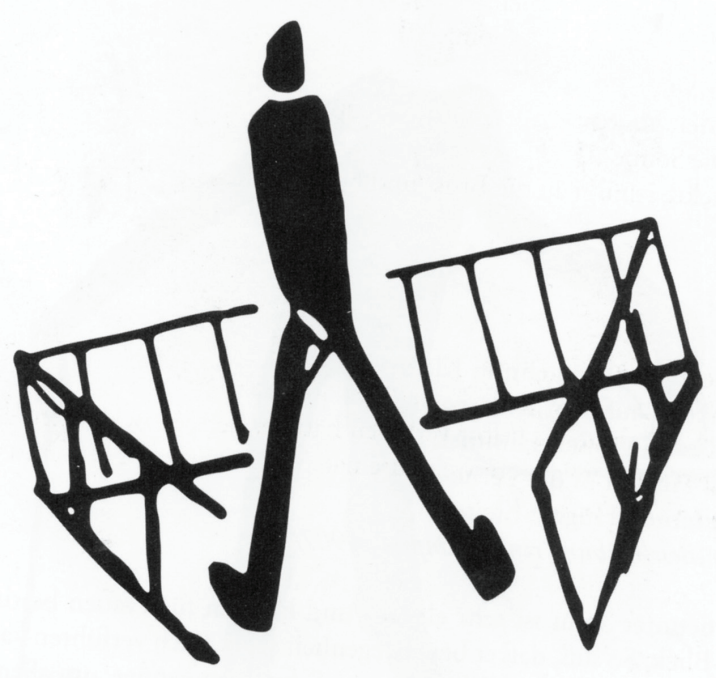

herfra [weg-von-hier]." Og igen en tredje gang: "Hele tiden væk herfra, kun sådan kan jeg nå mit mål." For tjeneren, som tilsyneladende ikke forstod den første befaling, eller måske ikke forstod sig selv som modtager af den, lader det nu til at være magtpåliggende at få svar på, om herren rent faktisk kender sit mål (das Ziel). Men herrens svar er forvirrende: "Ja," svarer han, "det sagde jeg jo." Hvorefter han angiver et stednavn i form af bindestregs-betegnelsen 'væk-herfra' (den term, hvormed Deleuze siden kobler Kafka sammen med et deterritorialiserings-projekt). Men hvad betyder det, når man siger, at 'væk-herfra' er 'mit mål'? Et hvilket som helst sted, der ikke er her, kan være væk-herfra, men så snart et sted bliver 'her', er det ikke længere 'væk-herfra', men bare et 'her' ligesom alle andre. Er der virkelig en vej væk herfra, eller følger 'her' med os, hvor end vi går hen? Hvad ville det indebære at blive frigjort fra de rumlige og tidslige vilkår, der er forbundet med 'her'? Det ville ikke alene kræve, at man var andetsteds, men også at selve dette andetsteds transcenderede alle eksisterende steders rumlige og tidslige vilkår. Så hvor end han har tænkt sig at tage hen, vil det ikke være et sted, der minder om det, vi forstår ved et sted. Er det da en teologisk parabel, der aftegner et usigeligt hinsides? Er det en parabel om Palæstina, det sted, der i den europæiske forestillingsverden, ifølge Kafka, er et ubefolket sted, et sted, der ikke kan bebos af nogen?

Han forekommer at være på vej til et sted, hvor det menneskelige legeme ikke har brug for næring. Tjeneren bemærker: 'Du har ingen proviant [Eßsvorrat] med.' 'Jeg behøver intet' sagde jeg, 'Rejsen er så lang, at jeg må dø af sult, hvis jeg ikke får noget på vejen. Ingen proviant kan redde mig [Kein Eßvorrat kann mich retten]."' Og så kommer den sælsomme afslutning: "Det er jo heldigvis en i sandhed uhyre rejse." Men hvad er det for en uhyrlig og ubegribelig rejse, hvor man ikke behøver spise noget? Ingen føde kan redde ham fra denne heldige færd ind i det uhyrlige. Heldigvis synes rejsen ikke kun at ville kræve hans sultedød - den vil heller ikke kunne redde ham og dermed fastholde ham et sted, der er et sted. Han er på vej til et sted, der ikke er et sted, og hvor der ikke er behov for føde. Hvis dette sted hinsides alle steder i sig selv er en frelse, hvilket dog ikke fremgår direkte, så vil det være en anden frelse end den frelse, føden yder levende væsner. Man kunne måske tale om en dødsdrift mod Palæstina, men man kunne også læse det som en åbning af en uendelig rejse eller en rejse ind i det uendelige med gestus til en anden verden. Jeg 
siger 'gestus', fordi det er den term, Benjamin og Adorno anvender i forbindelse med disse forstummede øjeblikke, disse ytringer, der ikke rigtig har karakter af handling, men derimod fryser fast eller størkner i deres egen forpurrede ufuldstændighed. Og det synes at være det, der sker her: En gestus åbner for et mål i horisonten, men der er ingen egentlig afrejse, og der vil bestemt ikke være nogen egentlig ankomst.

Ikke-ankomstens poetik går igen i Kafkas parabel "Messias' komme", hvor vi får at vide af en tilsyneladende autoritativ stemme, at Messias "vil komme, men først når ... ingen ødelægger denne mulighed, ingen tillader ødelæggelsen." (Kafka 1999, 74). Parablen refererer til en "hæmningsløs [zügellos] individualisme", som først må være mulig. Zügellos betyder egentlig nærmere 'løssluppen' eller 'frisat' en individualisme, der slippes løs i verden og er ude af kontrol. Det er der åbenbart ingen, der vil afstedkomme, og Messias forekommer ikke at ville antage menneskelig skikkelse: Messias vil først komme, når 'ingen’ ødelægger denne mulighed eller tillader ødelæggelsen, hvilket betyder, at Messias ikke vil komme, så længe der er 'nogen', men først når der ikke er nogen, og det betyder igen, at Messias ikke vil være nogen, ikke vil være et individ. Det må være resultatet af en særlig individualisme, der destruerer hver og et individ. I forlængelse af Matthæus Evangeliet hævder parablen, at "gravene åbner sig", hvor det er tydeligt, at de ikke vil blive åbnet ved nogen form for menneskelig indvirkning. Når fortælleren efterfølgende hævder, at dette også er "den kristne lære," markerer han med tilbagevirkende kraft parablen som jødisk, men faktisk er der allerede blevet etableret et veritabelt Babel af religioner med jødedom, kristendom og individualisme, og efter en forvansket redegørelse forekommer beskrivelsen også at være iblandet brudstykker af Hegel - der netop tegner sig for de mest ulæselige passager i parablen. Faktisk får man det indtryk, at der slet ikke er mulighed for en sammenhængende beskrivelse, og at man her er oppe imod grænserne for, hvad der overhovedet kan tænkes. "Messias vil først komme, når der ikke mere vil være brug for ham, han vil først komme efter sin ankomst, han vil ikke komme på den yderste dag, men på den alleryderste." Messias forekommer at ville komme netop, når der ikke er nogen til at tillade ødelæggelsen af verden, som vi kender den, når der ikke er nogen tilbage, der kan ødelægge hans komme. Denne Messias ankommer ikke som et individ og da slet ikke inden for den tidsfølge, vi opfatter som strukturerende for levende væsners verden. Hvis han kommer på den alleryderste dag, men ikke den yderste, vil det være en - hyper-figurativ - 'dag' hinsides enhver kalender og hinsides al kronologi. Parablen sætter en tidslighed, hvori ingen vil overleve. Ankomsten er et begreb, der tilhører kalenderens tid, hvilket tilsyneladende ikke gælder Kommet (das Kommen). Kommet indtræffer ikke på et bestemt tidspunkt, men først efter fuldbyrdelsen af alle tidspunkters sekvens.

Afrejse og ankomst var en stående problematik for de europæiske jøder, der overvejede at forlade Europa til fordel for Palæstina eller andre emigrationsmål. I "Opbruddet" står vi tilbage med spørgsmålet om, hvordan man kan komme væk herfra uden at bevæge sig fra et her til et andet? Forudsætter en sådan afrejse og ankomst ikke en distinkt tidslig bevægelseslinje hen over et spatielt kontinuum? Sammensætningen 'væk-herfra' fremstår som en stedsbetegnelse, der ikke har anden funktion end at nedbryde vores forestilling om sted i det hele taget. 'Væk-herfra' er et stednavn - det fastholder betegnelsen på et sted inden for en genkendelig gram- 
matisk form - men det viser sig, at grammatikken i dette tilfælde ikke kun afviger fra klar referentialitet, men tydeligvis også kan operere på tværs af enhver fattelig virkelighed. Der synes ikke at være nogen entydig måde, hvorpå man kan bevæge sig fra A til B inden for de rammer, der udstikkes i denne parabel, og det skaber forvirring i vores forestillinger om tidsfølge og spatiel kontinuitet. Det $g \varnothing r$ det ligefrem svært at følge linjerne på siden, at begynde på parablen og læse den færdig. Hvis Kafkas parabel i visse henseender kortlægger afvigelsen fra en gængs forestilling om bestandig ikke-ankomst, fører den heller ikke frem mod et fælles mål eller en progressiv indfrielse af et socialt mål på et specifikt sted.

Der er blevet åbnet for noget andet, den uhyrlige og uendelige distance mellem afrejse og ankomst - uden for den tidsfølge, hvori sådanne termer giver mening. I "Messias' komme" afviger Kafkas syn på ikke-ankomst fra de jødiske kilder - det tager udgangspunkt i dem og efterlader dem dér. Det bliver tydeligt, at uanset hvilken tidslighed der anslås af det messianske, så vil den ikke kunne realiseres i tid og rum. Her er der måske tale om et anti-kantiansk moment, en problematisering af jødedommen, som strækker den kantianske forestilling om fremtrædelsesform til det yderste på baggrund af en progressiv historieopfattelse med et sigte, der skal indfris i et befolket territorium.

Kafka reflekterer også over forskellige former for ikke-ankomst i et dagbogsnotat skrevet i 1922 mindre end to år, før han døde af tuberkulose:

6f Jeg har ikke vist den mindste standhaftighed eller beslutsomhed i min livsførelse. Det var, som om jeg, ligesom alle andre, havde fået et startpunkt, hvorudfra jeg kunne forlænge radiussen af en cirkel og så, ligesom alle andre, aftegne min egen fuldkomne cirkel rundt om dette punkt. I stedet begyndte jeg hele tiden på min radius på ny blot for igen og igen at blive tvunget til at afbryde den. (Eksempler: klaver, violin, sprog, germanistik, anti-zionisme, zionisme, hebræisk, havedyrkning, tømrerarbejde, skrivning, ægteskabsforsøg, at få min egen lejlighed.)

Det lyder jo sørgeligt, men så tilføjer han: "Hvis jeg indimellem forlængede radiussen lidt længere, end jeg plejede, for eksempel mit jurastudium eller forlovelserne, så gjorde denne lille ekstra afstand det hele værre og ikke bedre." Skal det forstås sådan, at der faktisk var noget, der blev bedre ved at afbryde udvidelsen af cirklens radius, ved at modsætte sig dens lukning? Kafka gør det klart, eller næsten klart, hvilke politiske implikationer hans forblommede teologi har, da han i januar 1922 beskriver den "vilde jagt", der er hans skriven. Eller måske er det ikke en jagt, gisner han, men et "angreb på den sidste jordiske ydergrænse" ligesom "al anden skrift af den art." Efterfølgende bemærker han: "Hvis zionismen ikke var kommet til, kunne det let have udviklet sig til en ny hemmelig doktrin, en kabbala. Noget kunne tyde på det."

Jeg har fors $\emptyset \mathrm{gt}$ at vise, at Kafkas parabler og andre skrifter rummer korte betragtninger over spørgsmålet om at tage et sted hen, om at krydse over, om umuligheden af ankomst og uopnåeligheden af et mål. Jeg vil mene, at mange af disse parabler fremstår som allegorier over en måde, hvorpå man kan lægge bånd på trangen til at emigrere til Palæstina, allegorier, der i stedet åbner en uendelig distance mellem det ene og det andet sted og dermed udgør en ikke-zionistisk teologisk gestus. 
Endelig kunne vi anskue denne ikke-ankomstens poetik i relation til Kafkas eget testamente. Det burde nu være klart, at mange af Kafkas værker handler om budskaber, der bliver skrevet ned og sendt til et sted, hvor ankomsten er usikker eller umulig, om befalinger, der bliver afgivet og misforstået og dermed bliver adlydt i strid med intentionen eller slet ikke. "Et kejserligt budskab" kortlægger en budbringers rejser gennem adskillige arkitektoniske lag, efterhånden som det går op for ham, at han er fanget i et finmasket og uendeligt net af mennesker: En uendelig barriere rejser sig mellem budskabet og dets destination. Hvad skal man så mene om den anmodning, Kafka rettede til Brod umiddelbart inden sin død? "Kære Max, mit sidste $\varnothing$ nske: Alt, hvad jeg efterlader mig ... bedes du brænde ulæst." Kafkas testamente er et budskab, der uomtvisteligt bliver afsendt, men det kommer ikke til indfrielse i Brods eget testamente. I såvel bogstavelig som overført betydning både adlyder og afviser Brods testamente Kafkas (en del af boet forbliver ulæst, men intet af det bliver brændt - i hvert fald ikke af Brod).

Interessant nok beder Kafka ikke om at få returneret sine skrifter, så han selv kan destruere dem. Tværtimod overlader han den uløselige gåde til Brod. Gennem brevet kan Kafka give hele forfatterskabet til Brod og samtidig bede ham påtage sig ansvaret for dets destruktion. Der ligger et uoverstigeligt paradoks her, eftersom brevet selv bliver en del af forfatterskabet og dermed kommer til at indgå i det tekstkorpus, der i lighed med mange andre af Kafkas breve er blevet omhyggeligt bevaret gennem årene. Samtidig stiller dette brev krav om en destruktion af skrifterne, som logisk set ville indebære en annullering af brevet selv og dermed en annullering af den befaling, det overbringer. Er denne befaling så en klar instruks, eller er den en gestus i Benjamin og Adornos forstand? Forventer han, at budskabet skal nå frem til sin destination, eller skriver han sin henstilling velvidende, at budskaber og befalinger aldrig når frem til dem, de er adresseret til, velvidende at de vil være underkastet den ikke-ankomst, han selv skrev om? Glem ikke, at det var Kafka, der skrev følgende:

64 Hvordan i alverden kom folk på den ide, at man kunne kommunikere med hinanden via breve! Man kan tænke på en fjern person, og man kan gribe fat om en person, der er lige i nærheden - alt andet overstiger menneskets kraft. Når man skriver breve blotter man sig derimod for spøgelserne, hvilket de grådigt afventer. Skrevne kys når aldrig frem, de bliver snarere opsnappet undervejs af spøgelserne. Det er på grund af denne righoldige fødekilde, at de formerer sig så voldsomt. Menneskeheden fornemmer dette og kæmper så vidt muligt for at eliminere spøgelseselementet mellem mennesker, og for at skabe en naturlig kommunikation, en sjælefred, har man opfundet jernbanen, automobilen, flyvemaskinen. Men det nytter ikke noget længere - alle disse ting er tydeligvis først blevet opfundet i sammenbruddets øjeblik. Modstanderne er langt roligere og stærkere; efter postvæsnet har de opfundet telegrafen, telefonen, radiografen. Spøgelserne kommer ikke til at sulte, men vi vil gå til grunde.

Hvis værkerne var blevet destrueret, ville det måske have berøvet spøgelserne deres næring, men Kafka kunne ikke have forudset nationalismens og profittens grænseløst parasitiske kræfter, selvom han vidste, at disse gespenster stod på spring. Som 
døende skriver Kafka så, at han ønsker sine skrifter destrueret efter sin død. Skal det forstås sådan, at skriften er knyttet til hans liv, og at forfatterskabet også bør dø, når Kafka selv afgår ved døden? Ved min død bør også mit værk ophøre at eksistere. Det er selvfølgelig fantasien om, at værket ikke må overleve ham - en alt for smertelig tanke for ham. Det minder mig om parablen "Familiefaderens bekymring", som pådrog sig Adornos bevågenhed i kraft sit løfte om 'frelse'. Her finder vi Odradek, en skabning, en spole, en stjerne, med en latter som lyden af raslende blade, der svæver over eller under eller i nærheden af trappen i et hus. Måske er han en søn, eller resterne af en søn, men i hvert fald er han dels objekt og dels ekkoet af en menneskelig tilstedeværelse. Først til sidst i parablen får man indtryk af, at den strengt neutrale stemme, der beskriver Odradek, står i en familiær relation til ham. Denne Odradek kan ikke rigtig siges at leve i tiden, for det fremgår af beskrivelsen, at han hele tiden - altså i al evighed - falder ned ad trappetrinene. "Den forestilling, at han ligefrem skulle overleve mig, volder mig næsten smerte," (Kafka 2008c, 177) bemærker fortælleren, der forekommer at have en faderposition i forhold til Odradek. Kunne man læse dette som en allegori, ikke blot over Kafkas position i sin egen fars hus, men også over hans skrift, de raslende sider, over de måder, hvorpå Kafka selv blev halvt menneske, halvt objekt uden efterkommere, eller rettere med et litterært afkom, som næsten voldte ham smerte ved den blotte forestilling om, at det kunne overleve ham? Den store værdi, Adorno så i Odradek, var hans totale ubrugelighed i en kapitalistisk verden, der søgte at instrumentalisere alle objekter med henblik på egen vinding. Det er imidlertid ikke kun teknologiens spøgelser, der har hjemsøgt Kafka og grådigt næret sig af hans skrifter, men også de former for profitskabelse, der udnytter selv de mest anti-instrumentelle kunstformer og de former for nationalisme, der søger at appropriere selv de skrivemåder, der modsætter sig nationalismen med størst ihærdighed. Det er således stærkt ironisk, at Kafkas skrifter endte som en andens ragelse, pakket væk i et skab eller en boks et sted, omdannet til bytteværdi, afventende et efterliv som ikon på et nationalt tilhørsforhold eller, slet og ret, som penge.

\section{Litteratur}

Kafka, Franz (1912): Rede über die jiddische Sprache. http://www.oppisworld.de/zeit/judentum/ jkafka.html.

Kafka, Franz (2008a): “Sjakaler og Arabere”, overs. Villy Sørensen i Fortællinger, København: Gyldendal. Kafka, Franz (2008b): “Opbruddet”, overs. Per Øhrgaard i Efterladte Fortællinger, København: Gyldendal. Kafka, Franz (1999): Aforismer, overs. Uffe Hansen, Roskilde: Roskilde Bogcafe.

Kafka, Franz (2008c): "Familiefaderens bekymring”, overs. Villy Sørensen i Fortællinger, København: Gyldendal.

Oversættelse Morten Visby.

Oprindeligt udgivet med titlen "Who Owns Kafka?" i London Review of Books, Vol. 33, nr. 5, 3. marts, 2011, pp. 3-8. Oversat med tilladelse af forfatteren og London Review of Books. 